committees and other formal and informal links for consultation. Besides the use of the development contract and an intelligent adaptation of the purchasing technique used by Mr. Robert McNamara in the United States, Lord Snow said that the Ministry proposed to make extensive use of listening. He stressed the value of Prof. P. M. S. Blackett's appointment on the Advisory Council on Technology, and agreed with Lord Todd's comments on the traditional industries and the research associations, also stressing the need to improve the status of the engineer.

Lord Snow's speech was generally welcomed in the debate, particularly by Viscount Mills, but although both the Earl of Halsbury and Lord Llewelyn-Davis welcomed the establishment of the Ministry of Technology they, as well as Lord Peddie, supported much that Lord Todd had said, as did the Earl of Bessborough. Lord Bowden, who replied on the debate as Minister of State for Education and Science, dealt more specifically with the educational aspect, and more especially with the question of attracting students to courses in subjects such as engineering or mathematics where Britain was experiencing a serious shortage of trained manpower. He welcomed the Earl of Bessborough's reference to the use of development contracts in the American universities, and assured the House that the two Ministries were as close together as it was possible for them to be. He also welcomed Sir Howard Florey's announcement regarding new fellowships of the Royal Society in applied science, and hoped that this would have its effect in the universities and in industry. The feature of both Lord Bowden and Lord Todd's speeches is the extent to which agreement on the organization of Civil Science and on the content of scientific policy cuts right across the bias of party politics. There may be disagreement as to timing or as to the measures to be used to effect particular purposes, but the extent to which agreement is shown to exist should itself encourage the response from scientists and technologists which Sir Howard Florey urged in his anniversary speech to the Royal Society.

\section{FIRST EDITION OF THE ORIGIN OF SPECIES}

\section{On the Origin of Species}

By Charles Darwin. Facsimile of the First Edition with an Introduction by Ernst Mayr. Pp. xxvii $+\mathrm{ix}+502$. (Cambridge, Mass.: Harvard University Press; London: Oxford University Press, 1964.) 48s. net.

1 HE Origin is one of the most important books ever published, and a knowledge of it should be a part of the intellectual equipment of every educated person. Darwin had hoped to produce his book in a leisurely manner. $\mathrm{He}$ had completed much of the work and the Origin seemed to be shaping into a large volume when, in the third week of June 1858, the postman delivered to him a letter which had been posted some weeks earlier in the Celebes Islands. In this, Alfred Russel Wallace, a travelling naturalist, had forestalled Darwin, for here was a sketch of his theory. The shock to Darwin was great; Lyell and Darwin suggested that an abstract of the theory from Darwin and Wallace should be communicated, and the two papers were read before the Linnean Society of London on July 1, 1858, but were received without great stir.

Darwin then commenced to abstract and condense what he had written, and after another year's work the first edition of the book was published with the sub-title "An Abstract" on November 24, 1859. The publishers did not expect a great demand for the book and printed 1,250 copies, which sold quickly. A second edition of 3,000 was produced in 1860 , a third in the following year, a fourth in 1866, a fifth in 1869 and a sixth and final edition in 1872. Darwin lived for another ten years; but he had so thoroughly sifted and reconsidered his data and inferences that he made no further changes in the book. Many reprints, translations and editions by others have appeared in a period of nearly a century, but almost invariably Darwin's own sixth edition has been used. Prof. E. Mayr, the author of a first-rate book on the Methods and Principles of Systematic Zoology, has provided a useful introduction and a new index to a facsimile reprint of the first edition. Thus, the student will be able to follow modifications in Darwin's thought over a period of more than a dozen years. In the earlier edition there is a forthrightness of assertion and, as in other editions, little technical language or professional jargon, so that the work is remarkably accessible to the layman. Darwin's power of marshalling his facts and systematizing the results of thousands of observations is manifest on every page.

There is little wonder that most of the philosophers did not love Darwin, for without recourse to metaphysical ideas he had invaded and conquered much of their territory. As Prof. Mayr points out, Darwin thought in terms of populations rather than of classical Platonic ideas, for, in the latter, the type (eidos) is real and variation an illusion. Thus, Darwin opened the way to the statistical concept which has proved so fruitful in research in biological and other sciences in the twentieth century. Prof. Mayr's introduction leaves us wishing for more. It could be read in conjunction with that of the late Sir Arthur Keith to the sixth edition (Everyman), in which are also printed the additions and corrections to the text in successive issues of the book, some notes on foreign editions and a historical sketch of the progress of opinion on the origin of species, previous to the publication of the first edition of this work.

In spite of Darwin's use of plain words and the tangible rather than the abstract, the book is not easy to read because of its concentration. It was indeed an abstract of a much larger work which was brought to a stop by Wallace's letter. The book will endure in future ages so long as a knowledge of science persists among mankind.

It remains to be said that the edition here reviewed is very worthily produced and contains a little-known picture of Darwin.

W. L. Sumner

\section{CHAPTERS OF QUATERNARY HISTORY}

\section{Animals and Plants of the Cenozoic Era}

Some Aspects of the Faunal and Floral History of the Last Sixty Million Years. By Dr. Ronald Pearson. Pp. vii +236 . (London: Butterworth and Co. (Publishers), Ltd., 1964.) 558.

$\mathrm{D}$ R. PEARSON'S book can porhaps be more accurately described as a series of essays on the history of the mammals and some groups of flowering plants in certain areas of the globe during the past sixty million years. Taken as essays, the chapters give useful summaries of some fields of research that are under active investigation, but there is all too little cross-linking from chapter to chapter.

We are told (p. 26) that a flora with tropical characteristics found at Comstock, Oregon, is of particular interest because it is associated with a marine fauna of known Eocene age. Marine faunas of the western United States are discussed on pp. 102-105, but there is no crossreference to the plants of the region. The London Clay flora is discussed, but all we are told about its interesting vertebrate fauna is that "the animal remains, with the exception of the Mollusca, are regarded as showing tropical 